
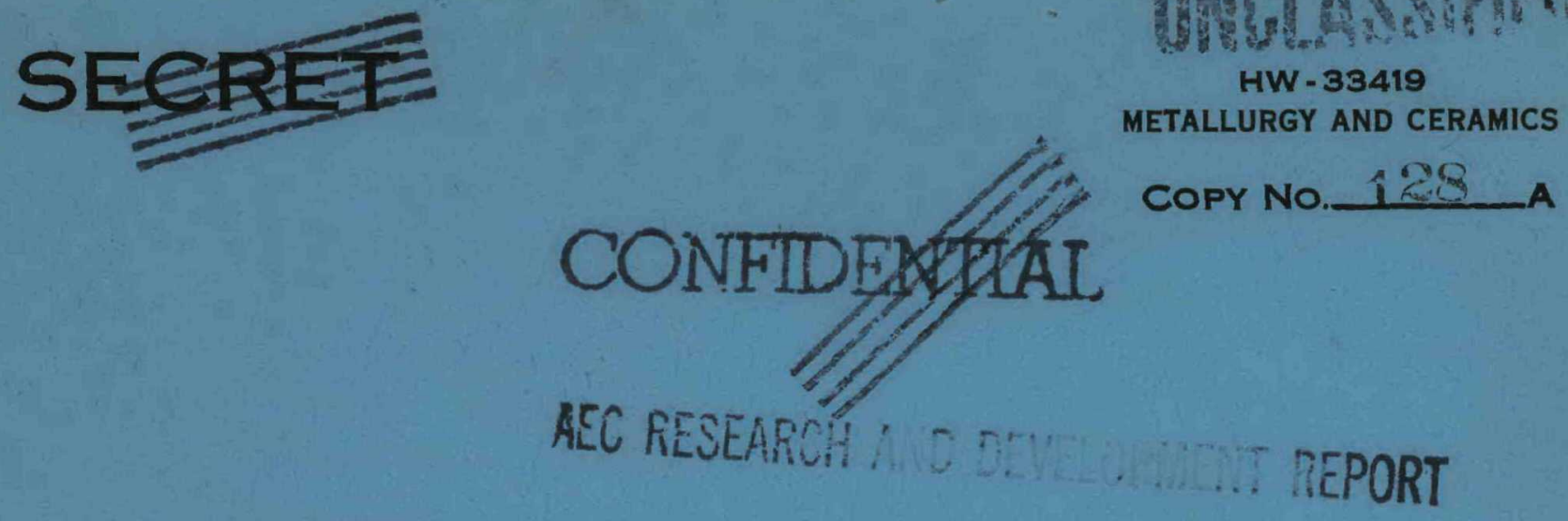

\title{
ZIRCONIUM CLADDING OF URANIUM
}

BY

P. J. PANKASKIE AND L. D. SCHAFFER

TECHNICAL SECTION

ENGINEERING DEPARTMENT

NOVEMBER 1, 1954

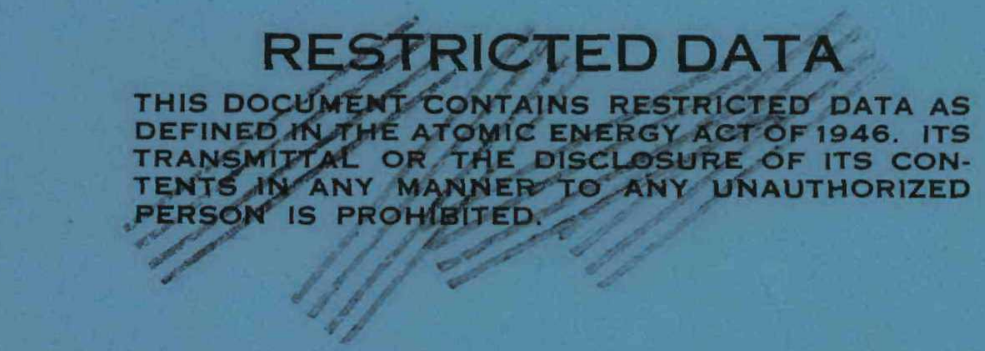

HANFORD ATOMIC PRODUCTS OPERATION RICHLAND, WASHINGTON

\section{GENERAL (g6) ELETRIC}
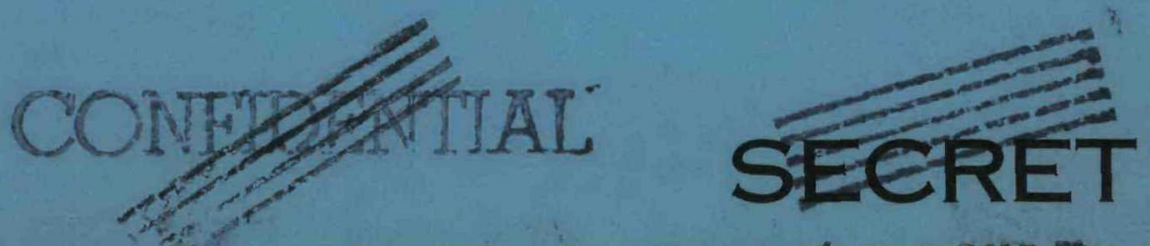


\section{DISCLAIMER}

This report was prepared as an account of work sponsored by an agency of the United States Government. Neither the United States Government nor any agency Thereof, nor any of their employees, makes any warranty, express or implied, or assumes any legal liability or responsibility for the accuracy, completeness, or usefulness of any information, apparatus, product, or process disclosed, or represents that its use would not infringe privately owned rights. Reference herein to any specific commercial product, process, or service by trade name, trademark, manufacturer, or otherwise does not necessarily constitute or imply its endorsement, recommendation, or favoring by the United States Government or any agency thereof. The views and opinions of authors expressed herein do not necessarily state or reflect those of the United States Government or any agency thereof. 


\section{DISCLAIMER}

Portions of this document may be illegible in electronic image products. Images are produced from the best available original document. 


\section{UNCLASSEP CUNEDERIM westions}

by mothority of

Wy

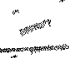

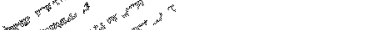

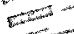

F

$H W-33419$

Metallurgy and Ceramics

This document consists of 28 pages. Copy No. of 142 copies. Series

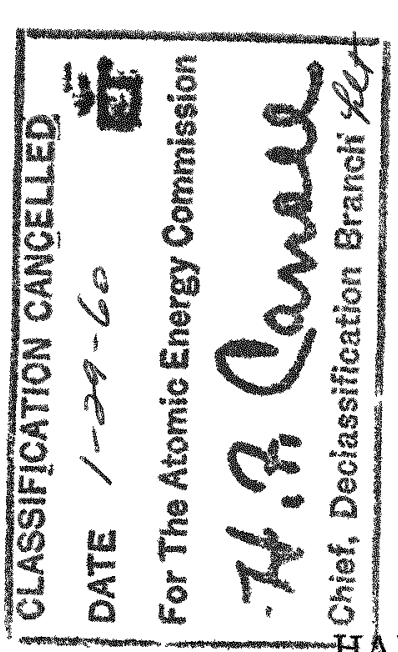

ZIRCONIUM CLADDING OF URANIUM

By

P. J. Pankaskie and L. D. Schaffer

Uranium Development Unit

Fuel Technology Sub-Section

Nove mber 1,1954

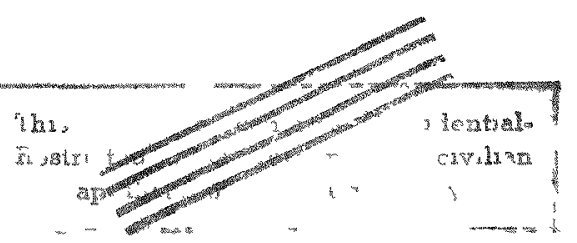

CLASSIFICATION GHANGED TO DATE $202-2$ ODNEW NIM

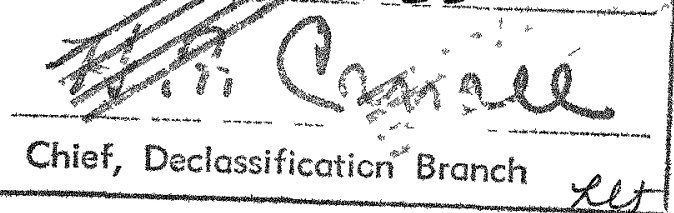

Operated for the Atomic Energy Commission by the General Electric Company under Contract W-31-109-Eng-52

\section{RESTRTCTED DATA}

This document contains Restricted Data as defined in the Atomic Energy Act of 1946. Its transmittal or the disclosure of its contents in any manner to an unauthorized person is prohibited.

\begin{tabular}{l|l|l|l|l}
\hline Route To: & Payroll No. & Location & Signature & Date \\
\hline & & & & \\
\hline & & & & \\
\hline & & & & \\
\hline
\end{tabular}

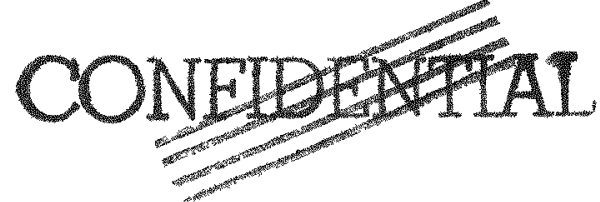

: :

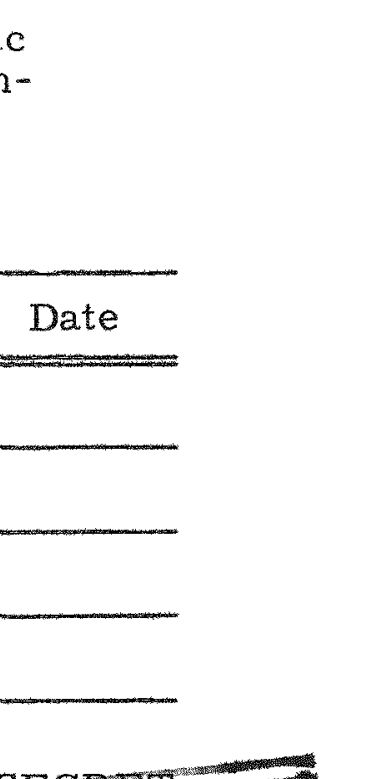

FT

RICHLAND, WASHINGTON 
INTERNAL DISTRIBUTION

\section{Copy Number}

1

2

3

4

5

6

7
F. W. Albaugh

J. A. Ayres

E. L. Armstrong

R. H. Beaton

L. P. Bupp - J. M. Atwood

J. J. Cadwell

A. C. Callen

A. B. Carson

V. R. Cooper

E. A. Eschbach

P. F. Gast

O. H. Greager

A. B. Greninger

W. T. Kattner

E. P. Lee

W. K. MacCready - W. J. Dowis

J. E. Maider - J. M, Fox, Jr。

W. M. Mathis

G. E. McCullough - R. W. Benoliel

E. W. O'Rorke

E. L. Reed

R. B. Richards

J. W. Riches

M. J. Sanderson - S. H. Bush

O. C. Schroeder

D. F. Snoeberger - A. G. Blasewitz

W. P. Wallace

O. J. Wîck

E. C. Wood

W. K. Woods - R. M. Fryar

L. D. Schaffer - P. J. Pankaskie 300 Files

Yellow Copy 


\section{EXTERNAL DISTRIBUTION}

AF Plant Representative, Seattle

AF Plant Representative, Wood-Ridge

American Machine and Foundry Company

Argonne National Laboratory

Atomic Energy Commission, Washington

Babcock and Wilcox Company

Battelle Memorial Institute

Bendix Aviation Corporation

Brookhaven National Laboratory

Brush Beryllium Company

Bureau of Mines, Albany

Bureau of Ships

Carbide and Carbon Chemicals Company (K-25 Plant)

Carbide and Carbon Chemicals Company (ORNL)

Chicago Patent Group

Commonwealth Edison Company

Detroit Edison Company

Dow Chemical Company (Rocky Flats)

duPont Company, Augusta.

duPont Company, Wilmington

Duquesne Light Company

Foster Wheeler Corporation

General Electric Company (ANPD)

General Electric Company (APS)

Hanford Operations Office

Iowa State College

Knolls Atomic Power Laboratory

Los Alamos Scientific Laboratory

Mallinckrodt Chemical Works

Materials Laboratory (WADC)

Monsanto Chemical Company

Mound Laboratory

National Advisory Committee for Aeronautics, Cleveland

National Bureau of Standards

National Lead Company of Ohio

Naval Research Laboratory

New Brunswick Laboratory

Newport News Shipbuilding and Dry Dock Company

New York Operations Office

North American Aviation, Inc.
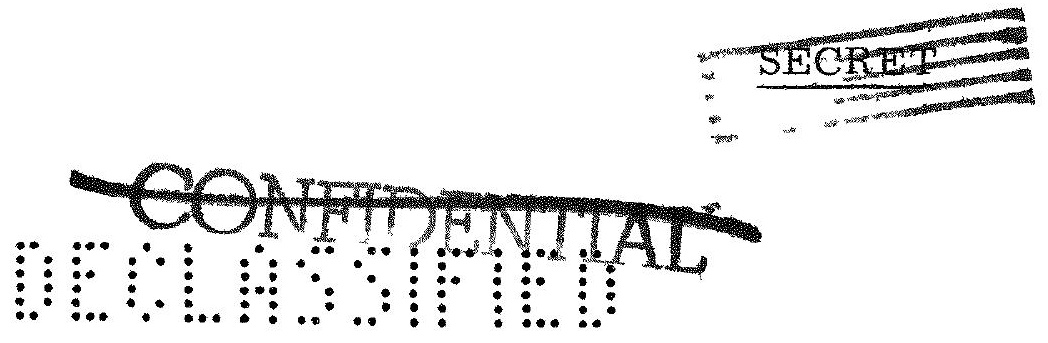


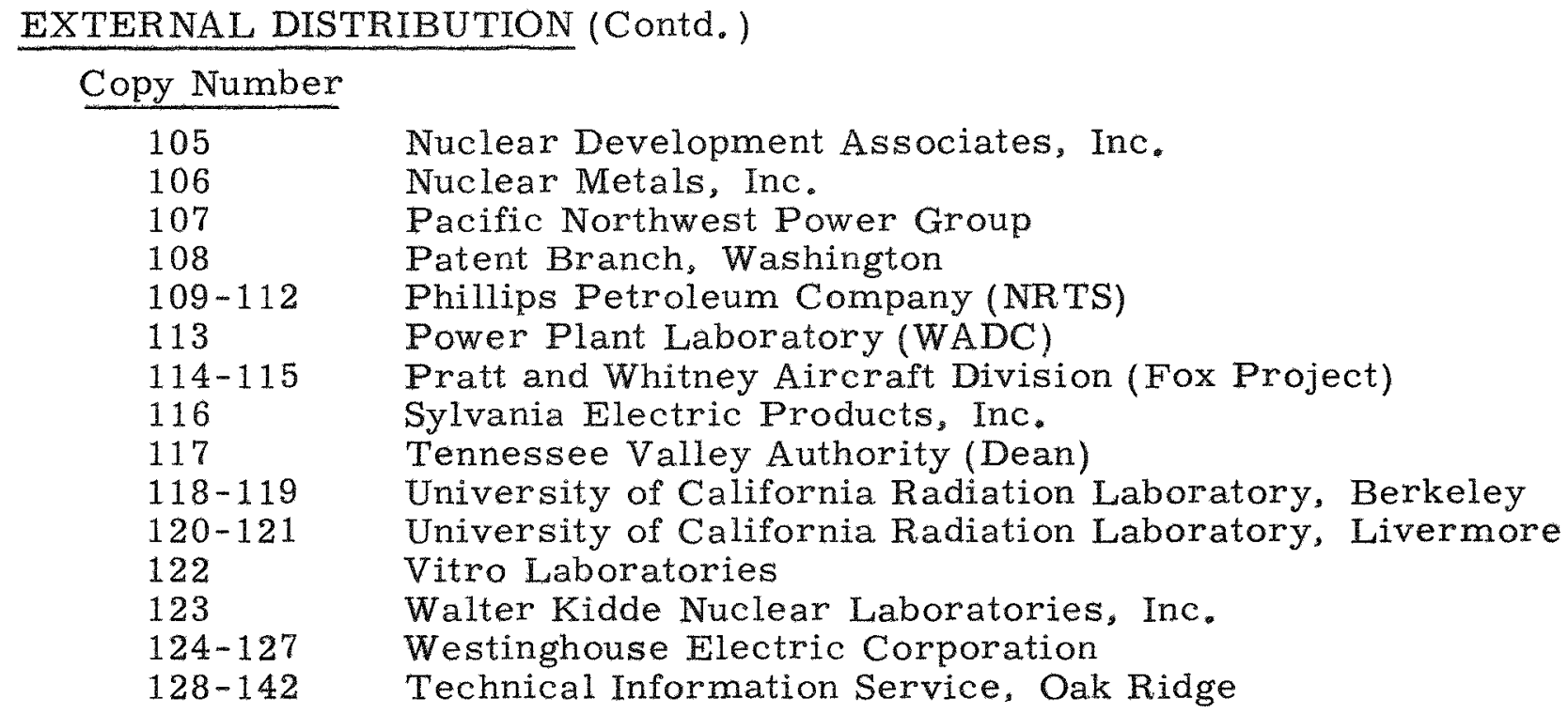




\section{ZIRCONIUM CLADDING OF URANIUM}

\section{INTRODUCTION}

Consideration of zirconium, including alloys of zirconium, as a material for coolant tubes possessing longer life than the present aluminum tubes $^{(1)}$ was a major factor for implementing efforts aimed at development of practical and economic methods for manufacture of zirconium clad fuel elements.

Over the past several years, methods have been developed at such sites as: Argonne National Laboratory, Battelle Memorial Institute, Westinghouse Atomic Power Division, and Nuclear Metals, Incorporated. Employment of heat, pressure and plastic flow were the basic principles involved in the development of cladding methods. Briefly, these methods were: roll bonding and co-extrusion. The former method was accomplished by the "picture frame technique" which involved pack rolling of uranium placed in a zirconium frame with zirconium cover plates $(2,3,4)$. The other method, developed primarily by Nuclear Metals, Inc., involved coextrusion of uranium encased in a rather close fitting zirconium can ${ }^{(5)}$.

From a standpoint of producing large quantities of solid round or perhaps tubular shapes, the "pack rolling" technique was not deemed practical and furthermore, a rather appreciable amount of component preparatory work was required prior to component assembly and final forming. The co-extrusion method appeared to be quite practical for production of solid, round, or tubular geometries but suffered from lack of peripheral uniformity of the jacket thickness unless some prior working was done or alloying additions made to the uranium core which refined the uranium core grain size.

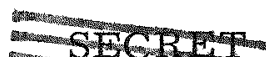


Early in 1953, Dr. O. N. Carlson of Iowa State College, experimented with casting into, as well as, melting uranium directly in zirconium containers. These experiments disclosed that the uranium bonded to the zirconium by interfacial alloying ${ }^{(6)}$. These experiments immediately suggested that a bonded zirconium jacketed fuel element might be made directly by casting molten uranium into a preformed zirconium shell of appropriate fuel element geometries. These experiments also suggested that the aforementioned methods, i.e.. "picture frame" and co-extrusion techniques, could be simplified and made more practical from an engineering and economic viewpoint.

This report describes the work which has been done at HAPO and in conjunction with other sites towards developing methods for cladding uranium with zirconium.

OBJECTIVE

The objective of the efforts, described in this report. was to develop techniques for producting a fuel element with a bonded zirconium or Zircaloy 2 jacket.

\section{SUMMARY}

A sound, ductile alloy bond can be achieved by casting molten uranium directly into a chemically cleaned zirconium shell under vacuum and proper mold preheat conditions. A ductile alloy layer is formed when the system heat balance is such that alloying occurs at the zirconium-uranium interface. The zirconium shell must also be preheated, by mass heat transfer or an external source, to a sufficiently high softening temperature, so that the uranium-zirconium alloy bond is not fractured during solidification and thermal contraction as the composite casting cools.

Bonded zirconium clad fuel elements of HAPO geometry have been made by direct "cast bonding" techniques. Experiments performed at HAPO, indicate that the "cast bonding" technique may be developed into a practical method for quantity production of fuel elements. 
Bonded zirconium clad ingots, weighing from 250 to 500 pounds, have been produced by casting directly into preformed zirconium molds. Small "cast bonded" billets, containing unalloyed uranium, have been experimentally extruded from the "as cast" condition at Nuclear Metals, Inc., and the co-extruded rods exhibit a unform cladding thickness ${ }^{(7)}$. Further experiments at KAPL ${ }^{(8)}$ disclosed that very low extrusion ratios (on the order of $6: 1$ ) can be employed and yet attain a bonded and uniformly clad rod. Rods from "cast bonded" ingots rolled in a diamond-round roll sequence at Simonds Saw and Steel Works, did not exhibit uniform jacket thicknesses.

The bend ductility of uranium in the "as rolled" condition, rolled from "cast bonded" ingots, is about four times greater than that exhibited by bare rolled uranium. After beta transformation, the bend ductility was better by a factor of about two.

DISCUSSION

The initial experimental work of determining the necessary conditions for achieving an alloy bond between $\mathrm{U}$ and $\mathrm{Zr}$ by direct casting was done by Dr. O. N. Carlson and co-workers at Iowa State College. The work described in this report represents a continuation of experimental and development efforts aimed at devising one or more practical methods for jacketing uranium with $\mathrm{Zr}$ or $\mathrm{Zr}$ alloys.

A. Description of Casting Experiments

In the initial work at HAPO, controllable mold preheat and temperature measuring equipment was not avalable in existing facilities. In the absence of the desired equipment, it was proposed to attempt a determination of proper bonding conditions by estimation from mass heat transfer and heat balance calculations. On this basis, several casting were made wherein the pouring temperature was varied from about $1200 \mathrm{C}$ to about $1450 \mathrm{C}$ and identical molds were employed. Initial molds consisted of $\mathrm{Zr}$ 
tubing of about $13 / 4$ inch diameter $\times 0.060$ inch wall thickness. On the assumption that the mold did not become heated by radiation or conduction prior to pouring, heat balance calculations indicated that an interfacial temperature of about $1100 \mathrm{C}$ minimum was necessary to achieve bonding of the $U$ and $\mathrm{Zr}$. Visual examination of castings wherein complete bonding had been achieved showed that the $\mathrm{Zr}$ had undergone complete recrystallization and some grain growth. Upon removal of a bonded casting, the grain structure of the Zr was visible to the unaided eye without chemical etching. It is to be noted, that all $\mathrm{Zr}$ molds were chemically cleaned in a $\mathrm{HNO}_{3}{ }^{-}$ $\mathrm{HF}-\mathrm{H}_{2} \mathrm{O}$ mixture prior to casting. It is also conceivable that heat etching or tinting may be responsible for the observed grain structure of $\mathrm{Zr}$ shells. Figure 1 shows several typical castings from the initial "cast bonding" experiments.

In several instances where rather heavy walled molds of about $11 / 2$ inch to 2 inch diameter $x 1 / 8$ inch to $1 / 4$ inch wall were used, castings upon removal from the furnace, were found not to be bonded and the U core was rather loose in the mold. Removal of the U core from the mold disclosed a core whose surface was greyish and very closely resembled the color of clean $\mathrm{Zr}$ metal. This phenomenon was interpreted as evidence that alloying of $U$ and $Z r$ had occurred and that the hot strength of the alloy layer was insufficient to cause the necessary $\mathrm{Zr}$ mold deformation required to conform to the core dimensions as the core solidifies and thermally contracts during cooling. The reader should bear in mind that the average coefficient of thermal expansion of zirconium is only about one-third that of normal uranium; hence the zirconium mold must deform plastically in order to adjust its dimensions to conform to those of the core as it solidifies and thermally contracts during cooling.

After installation of thermocouples in existing melting furnace facilities, several single and multiple casting experiments were made in an attempt to establish the minimum mold preheat temperature required 

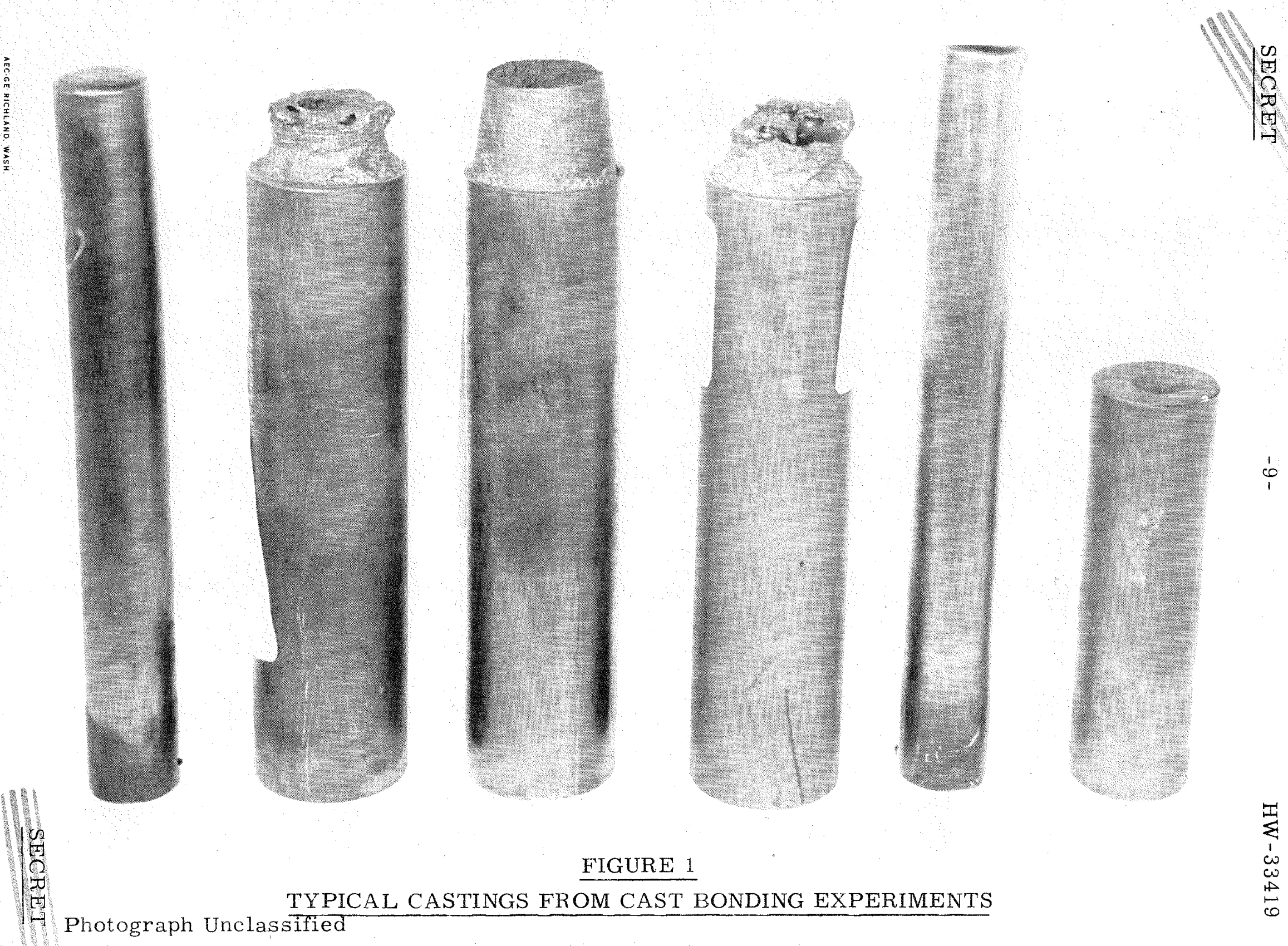
to promote bonding. In these experiments, the molds, in every case, consisted of deep drawn shells 1.44 inch diameter $\mathrm{x} 0.020$ inch wall $\mathrm{x}$ 10 inch long. In the single casting experiments, Chromel-Alumel thermocouples were placed in contact with the mold at positions of one-inch and eight-inches from the mold bottom and were held in position by a close fitting graphite sleeve which also served as the mold heater and crucible support.

In the multiple casting experiments, about twelve molds were affixed to a graphite reservoir so that molten uranium was gated simultaneously to each of the zirconium molds (See Figure 2). The zirconium molds and the graphite pouring reservoir were supported by steel sleeves and preheating was done by a hot plate, which also supported the entire system. Hence, in these cases, molds were preheated from the bottom only. Thermocouples were placed at the bottom of the mold and within a thermocouple well in the bottom of the graphite pouring reservoir.

In both sets of experiments, temperature measurements were made just prior to pouring, after pouring, and as the casting cooled to room temperature. The maximum pre- and post-pouring temperatures are presented in Table I. 


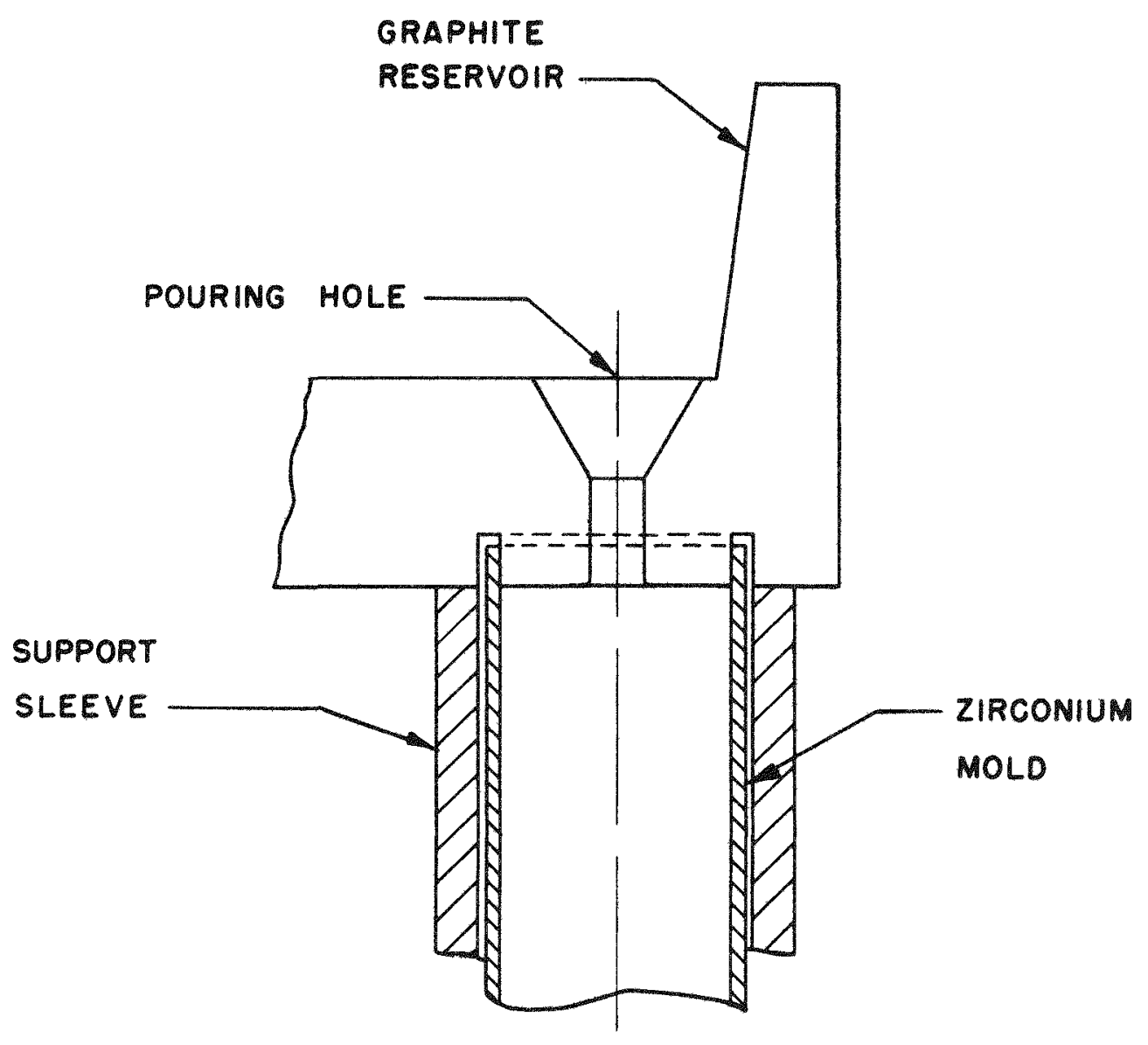

\section{SCHEMATIC ARRANGEMENT OF MULTIPLE CASTING SYSTEM}

FIGURE 2 


\section{TABLE I}

\section{CAST BONDING TEMPERATURE MEASUREMENTS}

MOLD TEMPERATURES

\begin{tabular}{|c|c|c|c|}
\hline \multicolumn{2}{|c|}{ Prior to Pour } & \multicolumn{2}{|c|}{ Post Pour } \\
\hline Bottom & Top & Bottom & Top \\
\hline Temp. & Temp. & Temp. & Temp. \\
\hline $320 \mathrm{C}$ & $998 \mathrm{C}$ & $698 \mathrm{C}$ & $1085 \mathrm{C}$ \\
\hline
\end{tabular}

(Single casting)

\section{2}

(Single casting)

\section{3}

(Multiple casting)

4 (Multiple casting)
$245 \mathrm{C} \quad 140 \mathrm{C} \quad 575 \mathrm{C}$

$375 \mathrm{C} \quad 100 \mathrm{C} \quad 530 \mathrm{C}$

$\begin{array}{lll}465 \mathrm{C} & 720 \mathrm{C} & 935 \mathrm{C} \\ & & \\ 245 \mathrm{C} & 140 \mathrm{C} & 575 \mathrm{C} \\ & & \\ 375 \mathrm{C} & 100 \mathrm{C} & 530 \mathrm{C}\end{array}$

Remarks

Complete bonded - Top TC and $\mathrm{Zr}$ shell reacted to form low melting compound.

$1080 \mathrm{C}$ Completely bonded - Both $\mathrm{TC}^{\prime} \mathrm{s}$ reacted with $\mathrm{Zr}$ shell.

$425 \mathrm{C}$ Castings were bonded at bottom - partially bonded at top.

$350 \mathrm{C}$ Bonded at bottoms, unbonded at top.

In the single mold casting experiments, it was observed, at about $900 \mathrm{C}$, that the zirconium and the Chromel-Alumel thermocouples (principally nickel) reacted for form a low melting compound and some uranium leakage occurred at these thermocouple contact points; reaction did not occur at $698 \mathrm{C}$. Hence, with the exception of this latter measurement, some error was introduced by the $\mathrm{Zr}-\mathrm{Ni}$ alloying. For these three instances, it was interesting to find that thermal arrests were observed at about $720 \mathrm{C}$ and $560 \mathrm{C}$, which are within about $100 \mathrm{C}$ of the transformation temperatures for $U+1.5 \%$ Si (atomic weight per cent).

In the case of the multiple casting experiments, the bottom thermocouples were in contact with the steel sleeves; hence some correction must be made to the measured temperatures. This correction has been estimated to be about $100 \mathrm{C}$. 
In the absence of sufficient mold preheating in the multiple casting equipment, several experimental castings were made wherein the zirconium mold were placed within a large graphite block (See Figure 13) and the entire assembly positioned so that the upper half is in the melting furnace induction coil. This system was designed to produce about 20 "cast bonded" slugs from a "single shot" pour. Attempts were made to measure mold preheat temperatures and, were found to be on the order of about $1100 \mathrm{C}$. A timetemperature chart is shown in Figure 4. Under these conditions, castings generally exhibited complete bonding of the uranium core to the zirconium jacket. Figure 5 shows the slugs from a single run.

On the basis of the foregoing experiments, it appears that a ninmum preheat temperature of about $350 \mathrm{C}$ is necessary to achieve bonding. Although transient conditions have not been treated rigorously, it appears that alloying occurs principally during wetting of the zirconium mold with molten uranium. From previous observations, it appears that the molds must reach a sufficiently high temperature to perhaps promote some solid state diffusion as well as soften the zirconium mold so that it readily deforms with the uranium core as it thermally contracts during cooling. Figure 6 shows the interface between the uranium and zirconium, and Figure 7 shows the uniformity of the zirconium jacket thickness of a composite casting. It is interesting to note that only very minute solution of the zirconium mold occurs and essentially no differences were noted over the range of temperatures encountered. Castings exhibit the same residual wall thickness at their top and bottom ends. Experiments at Iowa State College have shown that molten uranium can be cast into zirconium molds with wall thicknesses as low as two mils without complete penetration ${ }^{(6)}$. B. Experimental Forming of "Cast Bonded" Castings

The large grained structure, such as is found in "as cast" uranium, has generally been regarded as the cause of surface bumping which occurs during irradiation. It also appeared that there might be a desire for fuel 


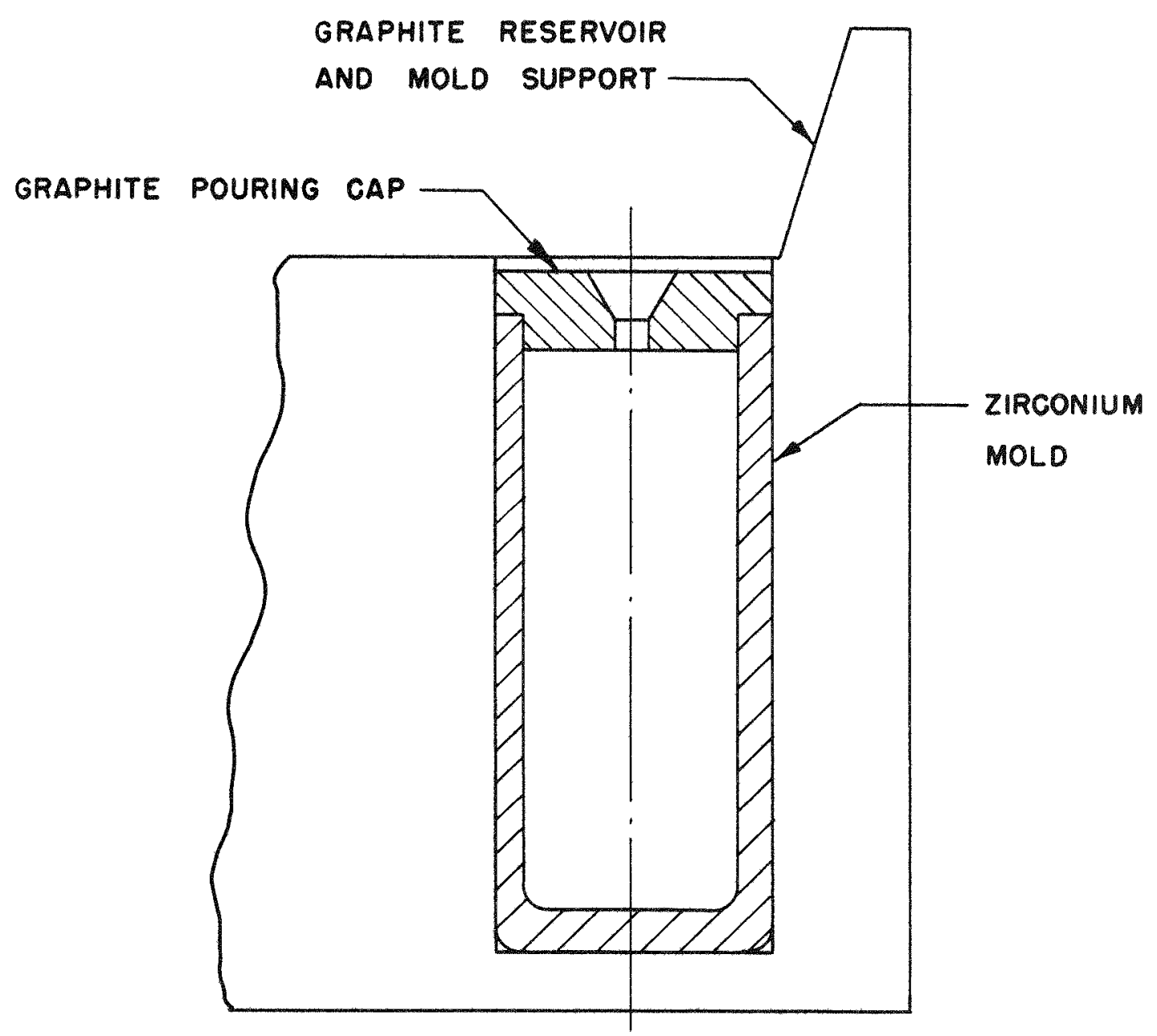

\section{SCHEMATIC ARRANGEMENT OF ALTERNATE MULTIPLE CASTING SYSTEM}

FIGURE 3 





SETET

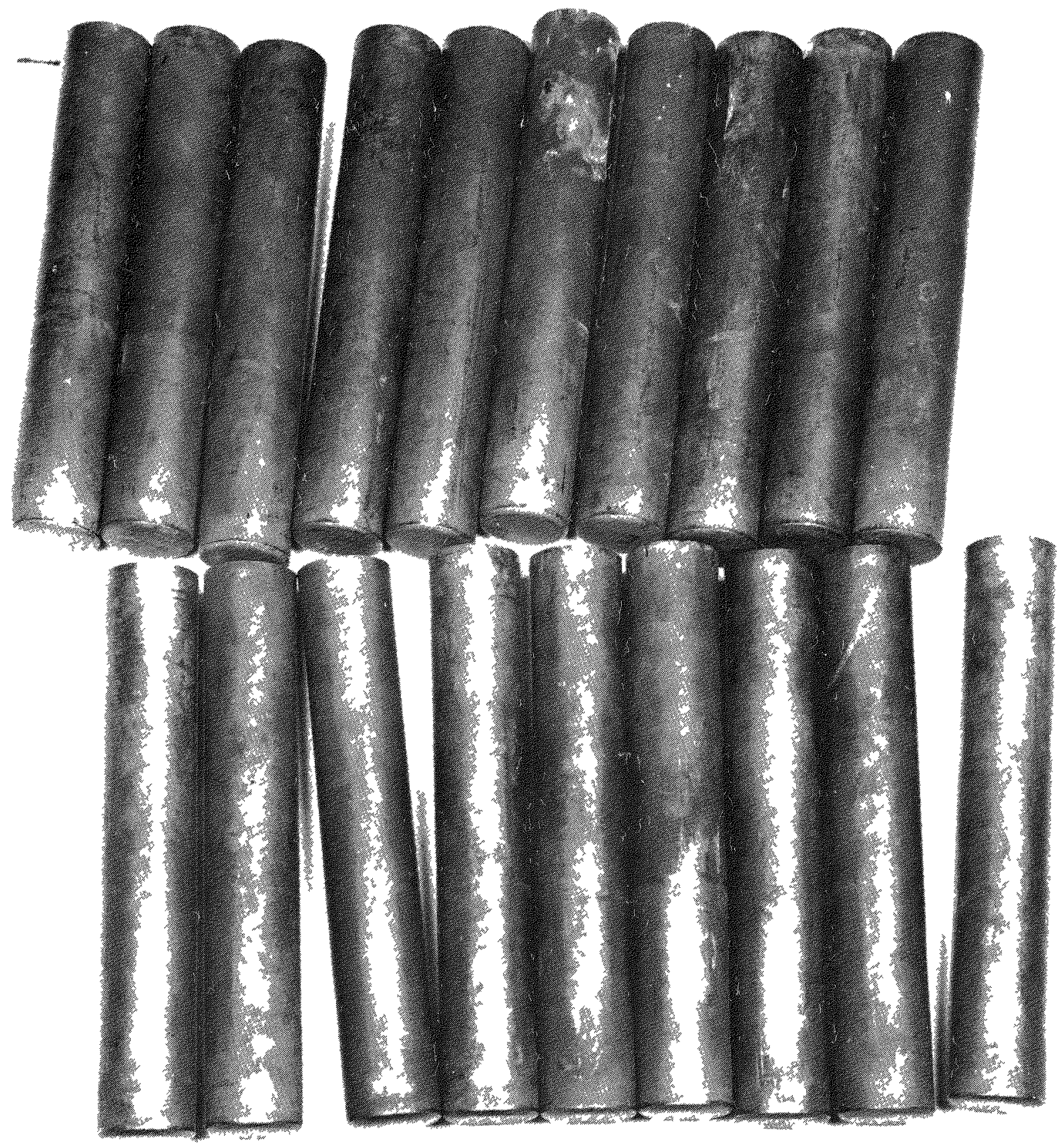

FIGURE 5

CAST BONDED SLUGS FROM A "SINGLE SHOT" POUR

Photograph Unclassified 


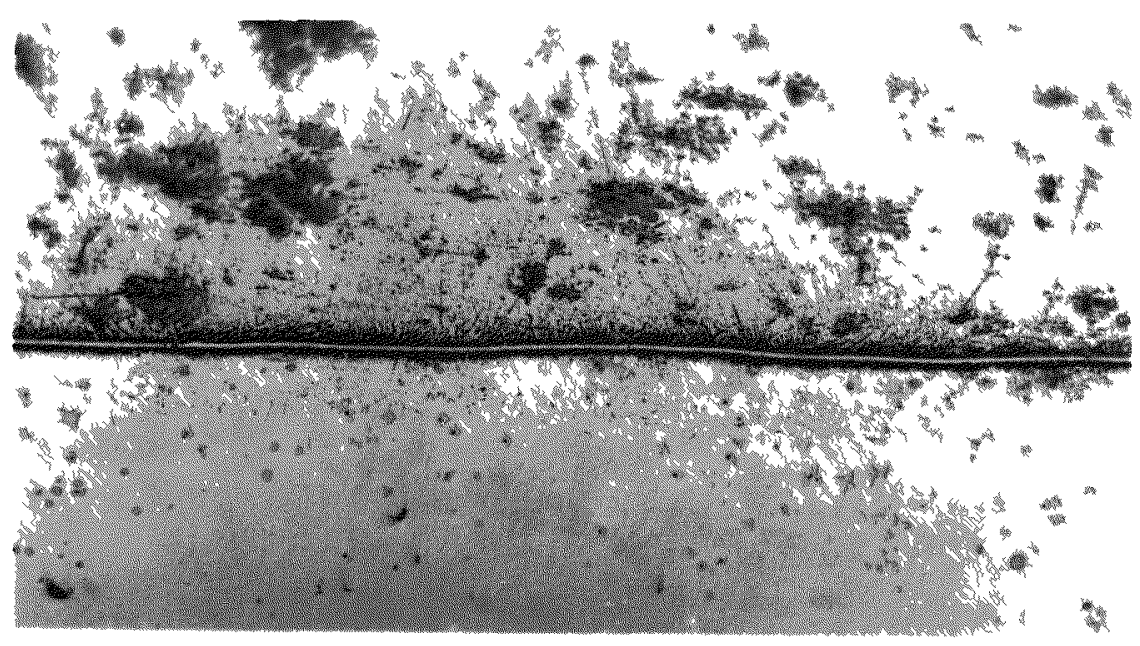

FIGURE 6. U - Zr interface showing alloying that occurs from pouring molten $\mathrm{U}$ into a preheated $\mathrm{Zr}$ mold. $\mathrm{Zr}$ at top, U at bottom. Mag. $250 \mathrm{X}$.

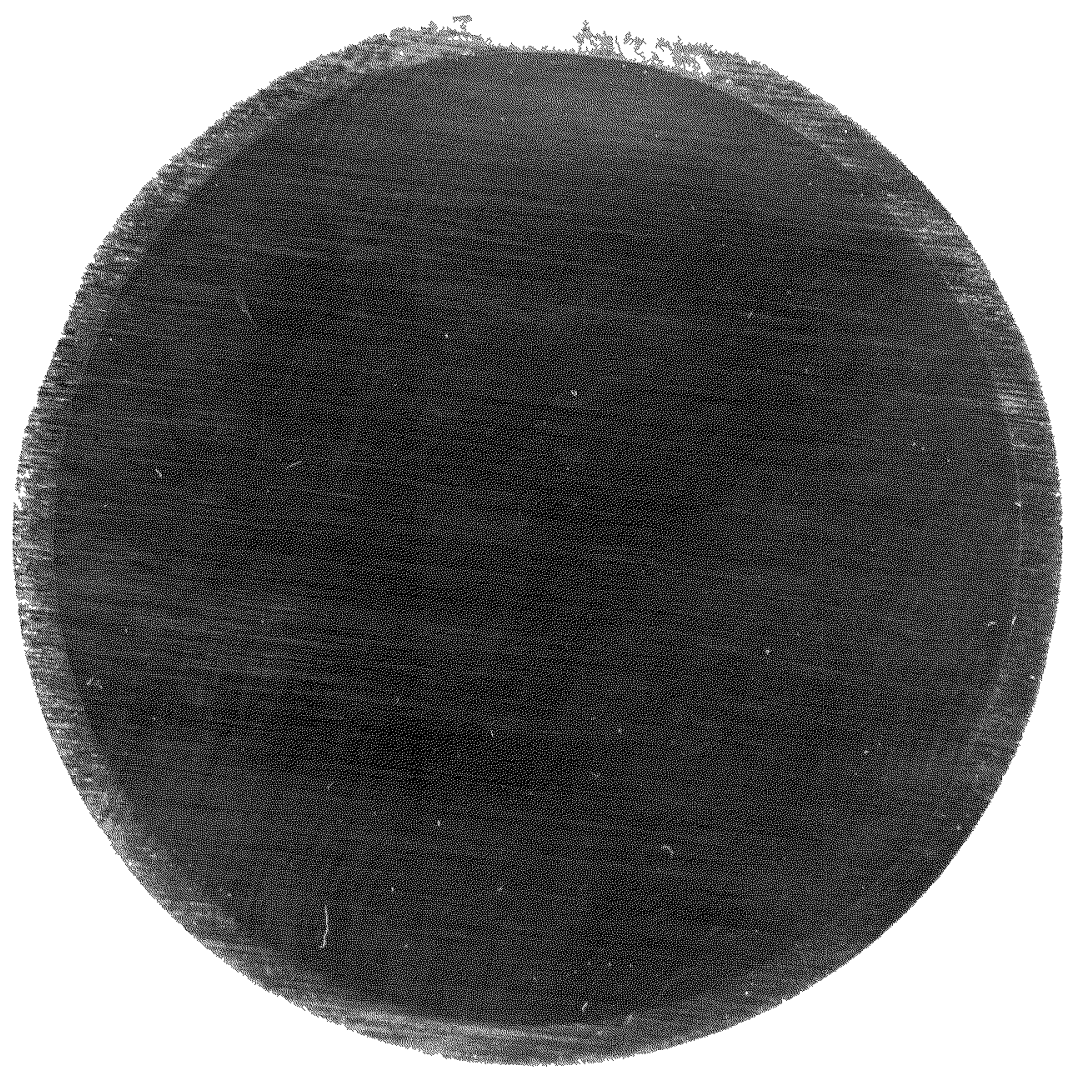

FIGURE 7. Cross section of composite casting made by casting molten $U$ into a $13 / 4^{\prime \prime} \mathrm{D}$ x $0.060 "$ $\mathrm{Zr}$ mold. Mag. 2.5X.

Photograph Unclassified 
elements of geometries that are not easily achieved by direct casting. On these permises, it was considered advisable to make some experimental attempts at forming the composite "cast bonded" ${ }^{B}$ castings to determine whether forming could be accomplished without detriment to the uraniumzirconium bond and yet achieve a satisfactory core structure.

A number of small castings were rolled in a six-inch laboratory mill employing oval-round roll sequences and salt bath preheating. It was learned that rolling could be accomplished in the high alpha phase temperature range without failure of the U-Zr bond. With the roll sequences available, it was found that uniform cladding thickness, around the periphery of the rolled rod, could not be achieved (See Figures $8,9,10$ ). The results were very similar to those achieved by co-extrusion of loosely canned uranium billets. Several large ingots were rolled, in diamond-round roll sequences at Simonds Saw and Steel Works, with similar results. As the total reduction in area increased, there was a tendency for the core to extrude out of the zirconium shell. Several small, "cast clad" billets were sent to Nuclear Metals, Inc. for extrusion into solid rod. Extrusion of a "cast bonded" billet with a normal uranium core, resulted in a clad rod with a rather uniform zirconium jacket thickness ${ }^{(6)}$ which is comparable to co-extrusions wherein the uranium core had been either appreciably alloyed or worked prior to co-extrusion to reduce the grain size of the uranium core.

C. Bond Testing

The initial test used to determine whether or not bonding of the U to $\mathrm{Zr}$ had been achieved was made by attempting to cut through the $\mathrm{Zr}$ with a chisel and peel of the shell. While an aluminum jacket can rather readily be removed in this fashion, the $\mathrm{Zr}$ shell was generally found to adhere rather tightly. 


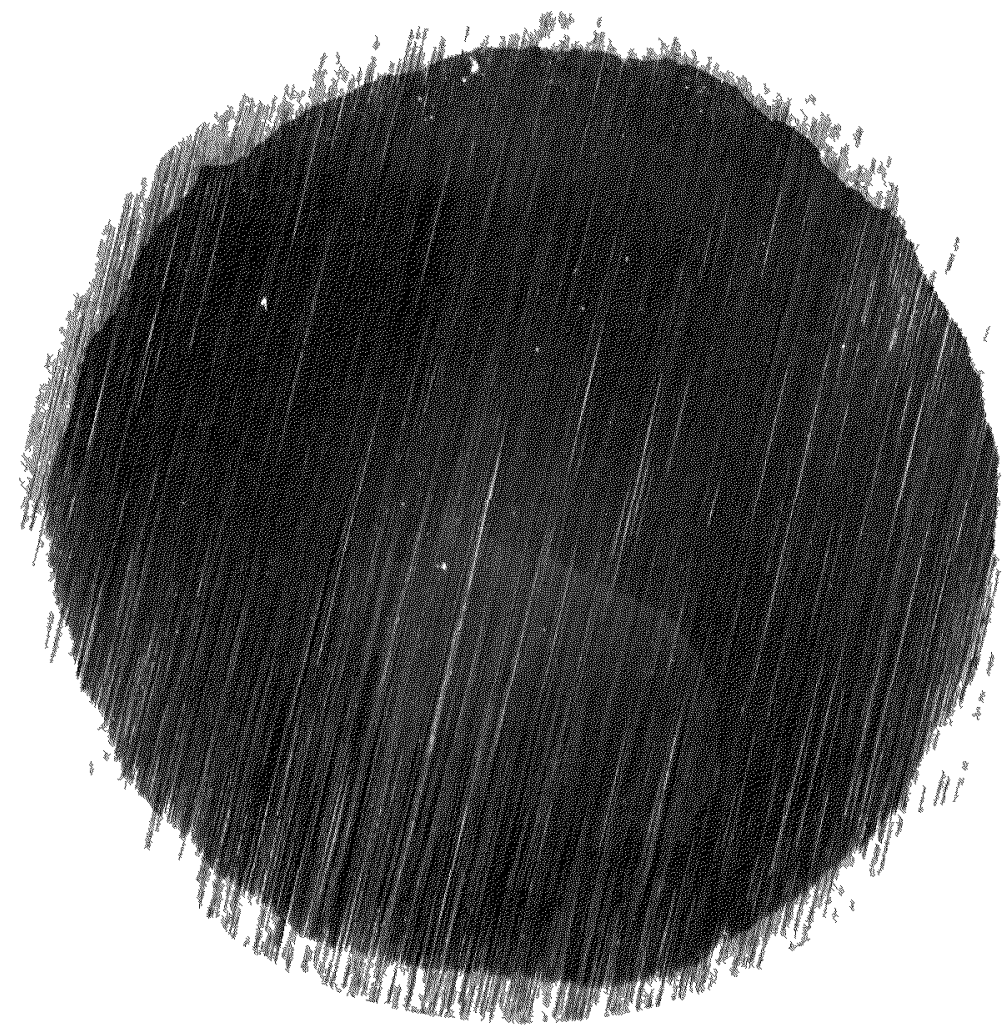

FIGURE 8. Cross section of $3 / 4^{\prime \prime} \mathrm{D}$ rod, alpha phase rolled from a $13 / 4 " \mathrm{D}$ casting. Note irregularity of jacket thickness. Mag. $51 / 2 \mathrm{X}$.

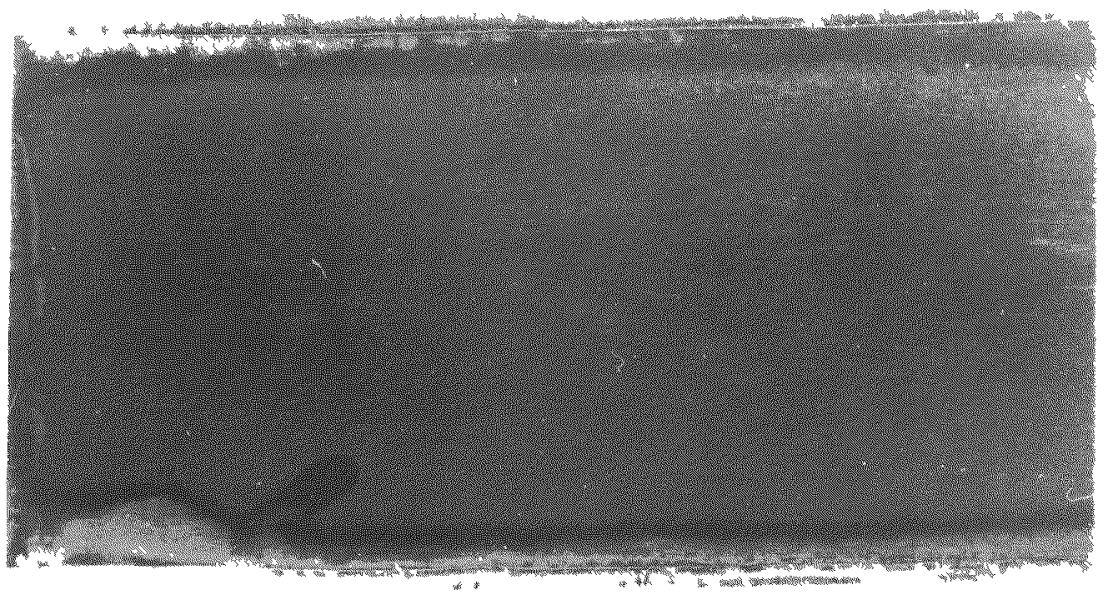

FIGURE 9. Longitudinal section of $3 / 4 " \mathrm{D}$, alpha phase rolled from a $13 / 4$ " D casting. Mag. $3 X$. Photographs Unclassified 


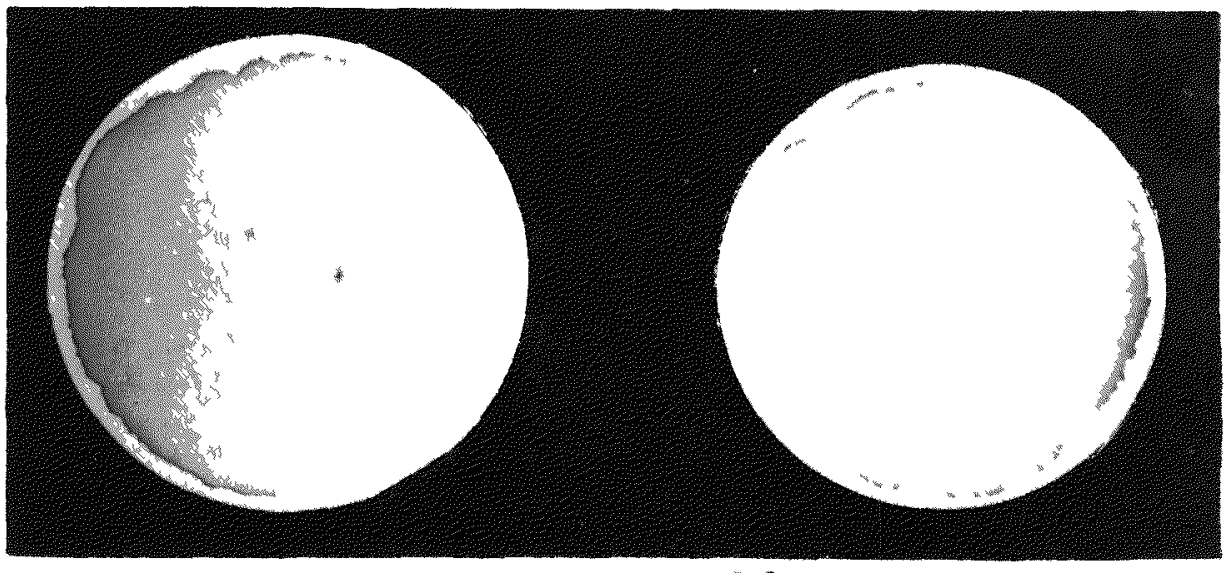

FIGURE 10. Cross section 5/16" D and 1/4" D rod cold swaged from a $1 / 2^{\prime \prime} D$ rod, alpha phase rolled from a $13 / 4^{\prime \prime} \mathrm{D}$ casting. Mag. $3 \mathrm{X}$.

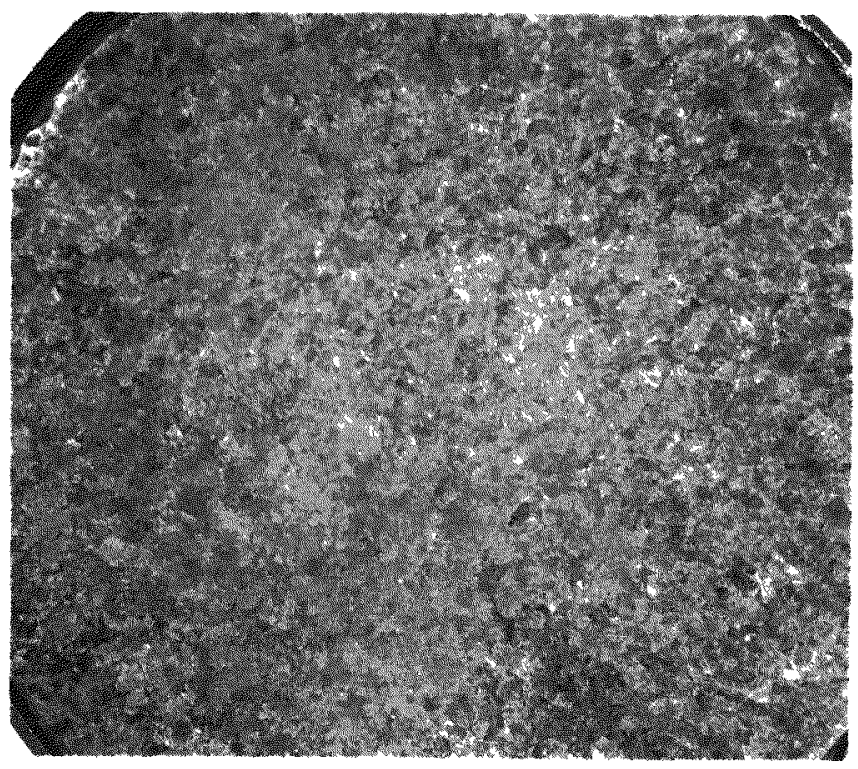

FIGURE 11. Macrostructure of cast and beta transformed $\mathrm{U}+1.5 \%$ Si (Atomic Weight Per Cent) alloy. Mag. 3X.

Photographs Unclassified 
In general, unbonded areas could be readily detected by visual examination. Unbonded areas are generally characterized by a blistered appearance. Striking a composite casting with a hammer, etc., produces the characteristic metallic ring if the shell and core are bonded and a dull sound if poorly bonded.

Several castings were cut longitudinally, heated into the $U$ beta and gamma phase temperature ranges and quenched into cold water without detriment to the $\mathrm{U}-\mathrm{Z} \mathrm{x}$ bond.

A composite casting was preheated in a salt bath to about $600 \mathrm{C}$ and rolled to $1 / 2$ inch diameter rod. A section of this rod was cut longitudinally and then bent through about $180^{\circ}$ over about a $1 / 2$ inch radius without detriment to the $\mathrm{U}-\mathrm{Zr}$ bond (See Figure 12).

D. Mechanical Properties

Mechanical properties of "as cast", cast bonded and alpha phase rolled and beta transformed material are presented in Table II along with typical averages for standard production material.

Tensile strength and ductility of "as cast" material are quite low as compared to standard production material and is considered to be attributable to the large grained, cast structure of the $U$ core.

The cast bonded material, after alpha rolling, exhibits somewhat higher tensile strength than is found in the standard production material without suffering a decrease in ductility. These differences are considered to be attributable to residual cold work (See Figure 13).

It is interesting, at this point, to note that the observed bend ductility of cast bonded and alpha rolled material was about four or more times greater than observed in material that was rolled bare under identical conditions of preheat, reduction and rolling sequence (See Figure 13). It was found that the clad rod could be bent through $180^{\circ}$ over a $1 / 2$ inch 


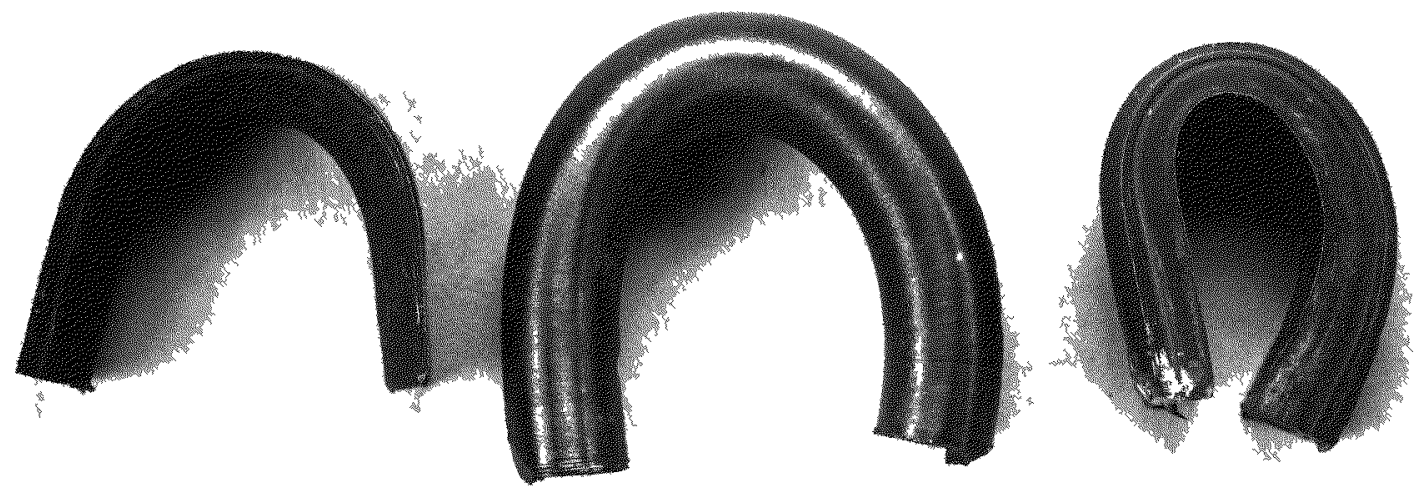

FIGURE 12. Test pieces of cast bonded and alpha rolled natural uranium showing ductility. Center piece had zirconium jacket removed by machining. Actual size.

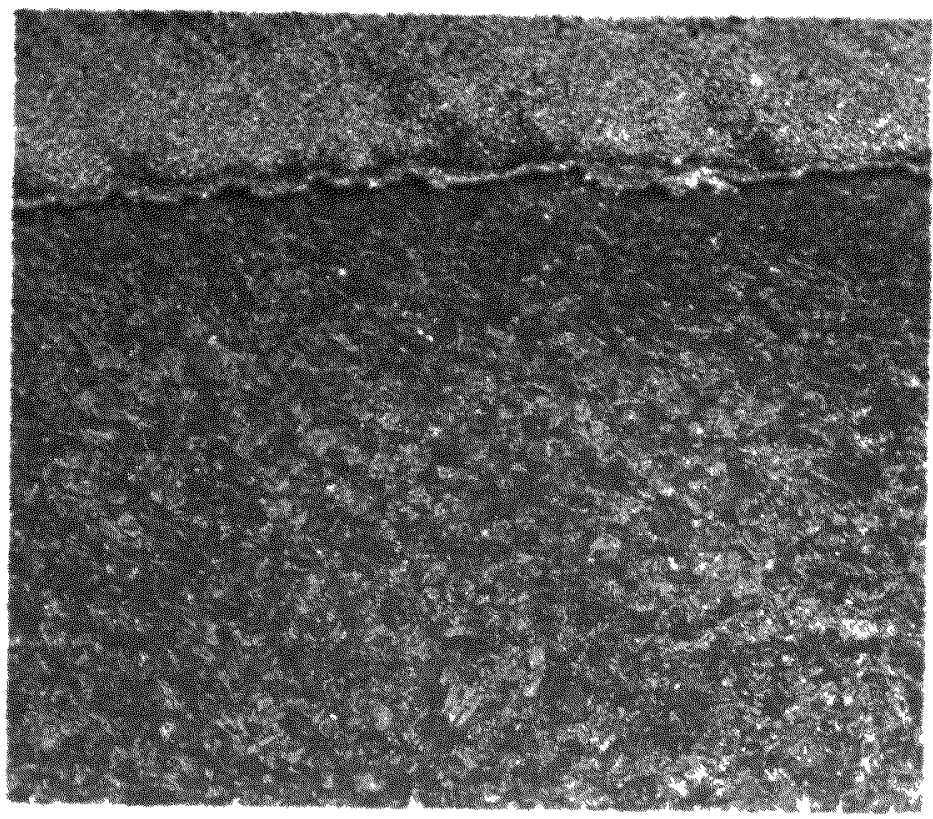

FIGURE 13. Microstructure of "cast bonded" and alpha rolled uranıum. Core exhibits a cold worked structure. Zirconium is at top. Note bond layer. Mag. 100X. 
TABLE II

\section{MECHANICAL PROPERTIES}

\begin{tabular}{|c|c|c|c|c|c|c|c|}
\hline Hardness & $\begin{array}{l}\text { Proportional } \\
\text { Limit - psi }\end{array}$ & $\begin{array}{l}\text { Yield } 0.2 \% \\
\text { Offset-psi }\end{array}$ & $\begin{array}{l}\text { Ultimate } \\
\text { psi }\end{array}$ & $\begin{array}{l}\text { Modulus } \\
10^{6} \text { psi }\end{array}$ & $\begin{array}{l}\text { Reduction } \\
\text { in Area \% }\end{array}$ & $\begin{array}{l}\text { Elongation } \\
\% \text { in } 2 \text { in. }\end{array}$ & $\begin{array}{l}\text { Test } \\
\text { Temp. }\end{array}$ \\
\hline
\end{tabular}

Temp.

Alpha Rolled from "Cast Bonded" Ingots (Hanford Recast)

$\begin{array}{lrrrrrr}\text { Average } & 10,000 & 39,200 & 132,000 & 22.1 & 18.5 & 20.0 \\ 96 \mathrm{R}_{\mathrm{B}} & 10,000 & 39,000 & 134,000 & 22.8 & 20.4 & 22.5 \\ \text { Average } & 8,800 & 38,800 & 135,000 & 22.7 & 19.2 & 17.0 \\ \text { Hardness } & 10,000 & 36,600 & 136,000 & 19.4 & 26.7 & 24.0 \\ \text { of cladding } & 10,000 & 37,900 & 137,000 & 21.0 & 25.9 & 23.5 \\ 81 \mathrm{R}_{\mathrm{B}} & 8,900 & 35,400 & 138,000 & 23.4 & 17.7 & 20.5\end{array}$

Alpha Rolled from "Cast Bonded" Ingots - Beta. Transformed

$\begin{array}{rrrrrr}6,300 & 36,300 & 99,400 & 21.0 & 10.4 & 14.5 \\ 11,400 & 34,800 & 97,100 & 23.5 & 9.4 & 14.0 \\ 11,400 & 36,400 & 98,000 & 20.8 & 11.4 & 11.5 \\ 16,400 & 37,900 & 98,600 & 16.1 & 11.2 & 13.5 \\ 11,300 & 36,300 & 97,800 & 18.9 & 12.0 & 13.5 \\ 8,800 & 34,400 & 95,300 & 22.5 & 9.7 & 12.0\end{array}$

Specimens from "As Cast" Normal Uranium Slugs

$\begin{array}{lcccccc}\text { Average } & 10,200 & 23,700 & 48,800 & 14.0 & 4.1 & 5.0 \\ 86 R_{B} & 14,800 & 28,400 & 60,700 & 28.0 & 7.5 & 4.5 \\ & 18,200 & 29,400 & 61,200 & 42.4 & 9.9 & 8.0 \\ & 10,200 & 22,200 & 58,900 & 31.2 & 3.1 & 6.5 \\ & -- & 31,500 & 48,900 & 49.2 & 4.5 & 4.0 \\ & 10,100 & 28,900 & 60,900 & 36.8 & 4.4 & 5.0\end{array}$

Alpha Rolled, Standard Production Material
7,400
36,400
108,000
21.4
17.0
20.0
Room

Alpha Rolled, Beta Transformed, Standard Production Material
7,300
35,500
94,900
21.2

12.4

13.8

$74^{\circ} \mathrm{F}$ 
radius without failure, while the bare material rarely could be bent through more than about $35^{\circ}$ without failure. After beta heat treatment, the bend ductility of the clad material is reduced to about one-half of its former value with the bare rolled material showing a proportionate decrease in bend ductility. These observations are interpreted as evidence that the ductility of $U$ is more adversely afftected through surface contamination by atmospheric gases (derived from molten salt baths) and at lower temperatures than for zirconium.

After beta transformation the clad and alpha rolled uranium exhibits mechanical properties which are quite comparable to production material.

Figure 14 shows the behavior of the "as cast", alpha rolled, and rolled and beta transformed material when subjected to biaxial stress conditions. Biaxial stressing was accomplished by subjecting heavy walled tubing to high internal pressures ${ }^{(9)}$; hence, these tests are a measure of transverse properties.

Curves 1 and 2 represent identical material except that the zirconium jacket had been removed by machining. Upon examination of curves 1 and 2 , it will be noted that the zirconium jackets appear to exert a strengthening effect but does not appear to effect the ductility. The ductility of this material appears to be superior to standard production (bare, salt bath rolled) material ${ }^{(9)}$. The alpha rolled, beta transformed material exhibits the greatest ductility and there appears to be some strengthening effect as the uranium approaches its ultimate strength and ductility as evidenced by the change in slope in the latter portion of the load-elongation curve. Elongation is comparable to standard production, beta transformed material ${ }^{(10)}$. The "as cast" material exhibits intermediate ductility and low yield and ultimate strengths and is considered to be primarily attributable to the large grained, cast structure. The castings, selected for test specimens, were of poor quality and contained a considerable amount of cold shuts and unbonded areas. 


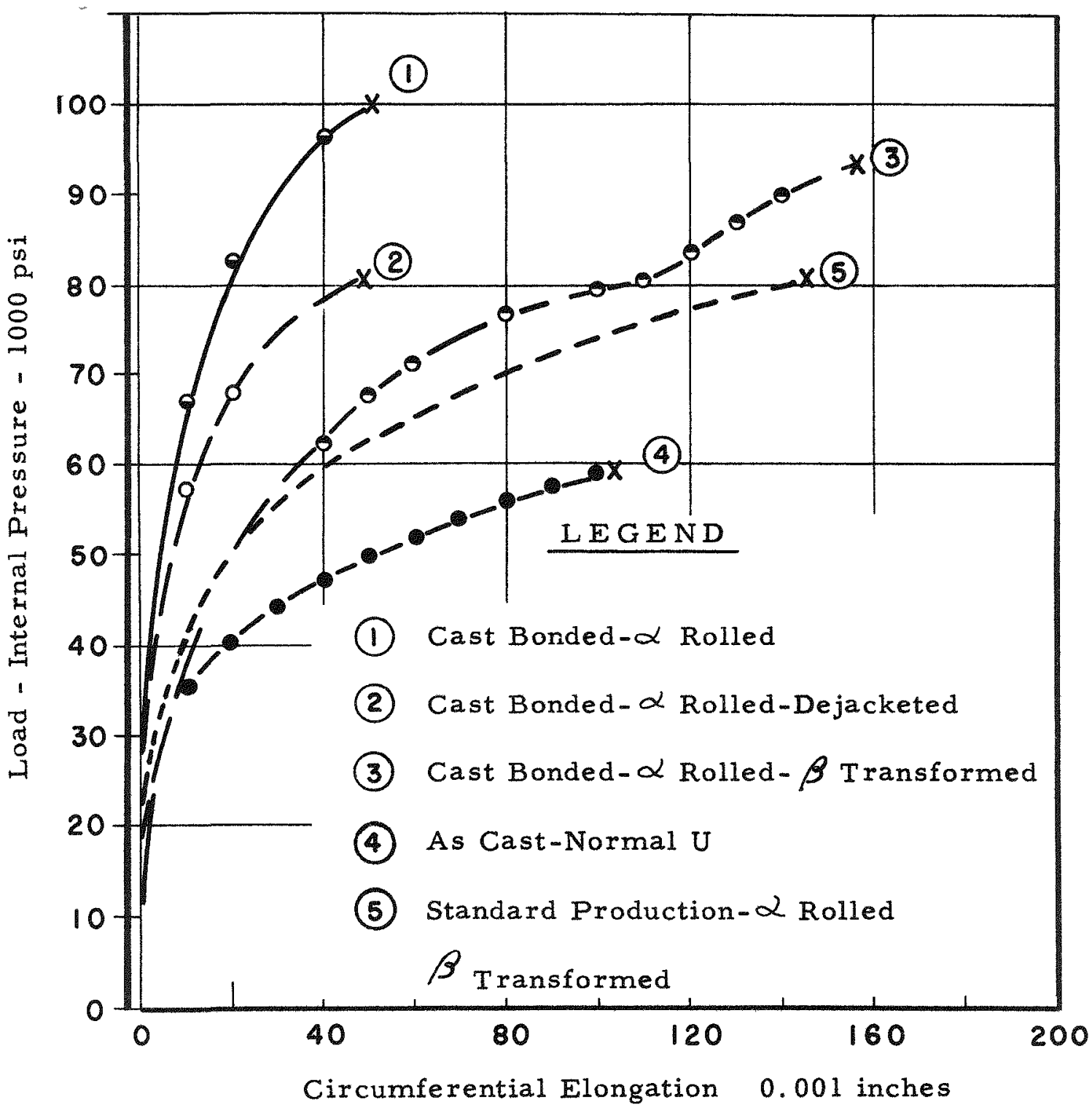

FIGURE 14

COMPARISON OF DUCTILITY UNDER BIAXIAL LOADING 
None of the cast bonded and co-extruded uranium was available for testing and inclusion in this report.

\section{CONCLUSIONS}

Under proper conditions of vacuum and mold preheat, a sound ductile alloy bond can be achieved by casting molten uranium into zirconium and Zircaloy 2 molds. Investigations to date, indicate that a process for production of zirconium or Zircaloy 2 clad fuel elements can developed by casting directly into preformed shells.

Employment of cast bonding techniques appears to be a simple and practical method for assembling extrusion billets. It also appears that co-extrusion of cast bonded normal. uranium billets produces a clad rod exhibiting a rather uniform cladding thickness and may permit greater freedom in selection of extrusion conditions to produce a clad and bonded geometry.

Forming of cast bond ingots in diamond-round or oval-round sequences failed to produce a clad rod with uniform jacket thickness. Subsequent forming operations failed to rectify non-uniformities in jacket thicknesses once they had occurred.

Further investigations should be undertaken to establish more firmly the range of casting conditions which are compatible to uraniumzirconium alloying and the effects that such conditions exert on mechanical properties of the components as well as forming characteristics of the composite castings. 
SECRET

$-27-$

$\mathrm{HW}-33419$

ACKNOWLEDGEMENTS

The authors wish to acknowledge the efforts of F. M. Ritter who performed the multiple casting experiments and to members of the Applied Research Sub-Section for providing mechanical property and metallographic data.

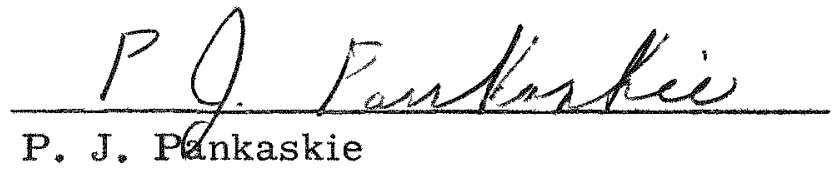

PJP:LDS:jw

QD. Shaffer

L. D. Shaffer

SECRET 


\section{BIBLIOGRAPHY}

(1) HW-26560, "Evaluation of Zirconium as Tube and Slug Jacket Material", P.J. Pankaskie and A. T. Taylor.

(2) ANL-5076, "Development of Zirconium Clad Uranium Plates for Reactor Fuel", J. J. Lawless, C. H. Bean, J. R. Wooland, and R. E Macherey.

(3) BMI-58, "Fabrication of Experimental Zirconium Clad ZirconiumUranium Alloy Fuel Elements", G. H. Schippereit, J. G. Kura, and L. W. Eastwood.

(4) BMI-841, "Core Shapes of Fuel Elements Clad with Zirconium Alloy", J. W. Holladay, J. G. Kura, and J. H. Jackson.

(5) MIT-PL-12, "Fabrication of Zirconium Clad Uranium Fuel Elements", P. Lowenstein.

(6) ISC-314, 346, 389, and 485, "Quarterly Summary Research Report, Iowa State College', F. H. Spedding, et. al.

(7) MIT-1115, "Technical Progress Report", A. R. Kaufmann, et,al.

(8) Personal Communications with Drs. D. W. White, C. E. Lacey, and C. J. Beck.

(9) Unpublished work by L. D. Schaffer. (HW-33466)

(10) HW-33418, "Alpha Extruded Uranium", P. J. Pankaskie and L. D. Schaffer. 


\section{BIBLIOGRAPHY}

(1) HW-26560, "Evaluation of Zirconium as Tube and Slug Jacket Material", P.J. Pankaskie and A. T. Taylor.

(2) ANL-5076, "Development of Zirconium Clad Uranium Plates for Reactor Fuel', J. J. Lawless, C. H. Bean, J. R. Wooland, and R. E Macherey.

(3) BMI-58, "Fabrication of Experimental Zirconium Clad ZirconiumUranium Alloy Fuel Elements", G. H. Schippereit, J. G. Kura, and L. W. Eastwood.

(4) BMI-841, "Core Shapes of Fuel Elements Clad with Zirconium Alloy", J. W. Holladay, J. G. Kura, and J. H. Jackson.

(5) MIT-PL-12, "Fabrication of Zirconium Clad Uranium Fuel Elements", $P$. Lowensteín.

(6) ISC-314, 346, 389, and 485, "Quarterly Summary Research Report, Iowa State College', F. H. Spedding, et. al.

(9) Unpublished work by L. D. Schaffer. (HW-33466)

(10) HW-33418, "Alpha Extruded Uranium", P. J. Pankaskie and L. D. Schaffer. 